\title{
SOSIALISASI PENGGUNAAAN KANTONG TATAKURA UNTUK MENGURANGI MASALAH LIMBAH PADAT RUMAH TANGGA
}

\author{
(The Socialization Of Using Tatakura Cards To Reducing The Household Solid Waste Problems) \\ Kamaliah, Nani Apriyani dan Sari Marlina \\ Program Studi Teknik Lingkungan Fakultas Teknik \\ Universitas Muhammadiyah Palangkaraya \\ JI. RTA Milono Km.1,5 Palangka Raya, Kalimantan Tengah 73111 \\ e-mail : kamaliahchua@gmail.com
}

\begin{abstract}
Household solid waste produced from households can be processed into compost by using takakura sacs. The purpose of this activity is to give information to the community in Kelurahan Kalampangan about the using of Takakura sacs in making compost from household solid waste. The implementation of this activitiy carried out by delivery information and demonstration methods. The activity was held on Wednesday, January 20, 2016, at 13:30 to 17:00 pm. The event began with the opening, the delivery of materials using the media leaflet followed by questions and answers. The material presented was a way of making starter to facilitate the decay of household solid waste and the using of Takakura sacs to make compost. This activity was successfully implemented because of the positive response and enthusiasm from the women of farmer group in Kelurahan Kalampangan.
\end{abstract}

Keywords: Takakura sac, household waste, compost.

\begin{abstract}
Abstrak
Limbah padat rumah tangga yang dihasilkan dari rumah tangga dapat diolah menjadi kompos melalui penggunaan kantung takakura. Tujuan kegiatan ini adalah memberikan informasi kepada masyarakat di Kelurahan Kalampangan tentang penggunaan kantung Takakura untuk pembuatan kompos dari limbah padat rumah tangga. Pelaksanaan kegiatan dilakukan dengan metode penyuluhan dan demonstrasi. Kegiatan dilaksanakan pada hari Rabu tanggal 20 Januari 2016, pukul 13.30 sampai pukul 17.00 WIB. Acara dimulai dengan pembukaan, penyampaian materi menggunakan media leaflet dilanjutkan dengan melakukan tanya jawab. Materi yang disampaikan dalam penyuluhan ini adalah cara pembuatan starter untuk memudahkan pembusukan limbah padat rumah tangga dan penggunaan kantung Takakura untuk membuat kompos. Kegiatan ini berhasil dilaksanakan karena adanya respon yang positif dan antusiasme dari ibu-ibu persatuan tani Kelurahan Kalampangan.
\end{abstract}

Kata kunci: kantung Takakura, limbah rumah tangga, kompos. 


\section{PENDAHULUAN}

Limbah adalah buangan yang dihasilkan dari suatu proses produksi baik industri maupun domestik (rumah tangga). Tempat pemukiman masyarakat merupakan sumber berbagai jenis limbah. Limbah padat yang lebih dikenal sebagai sampah seringkali tidak dikehendaki kehadirannya karena dianggap tidak memiliki nilai ekonomis. Pengelolaan lingkungan hidup merupakan kewajiban bersama berbagai pihak baik pemerintah, pelaku industri dan masyarakat luas.

Limbah padat dapat menjadi sangat merugikan bagi lingkungan jika limbah tidak dikelola dan diolah dengan baik untuk menjadikannya bermanfaat.

Permasalahan yang terjadi di masyarakat adalah pemikiran bahwa limbah padat yang dihasilkan dari rumah tangga masih dianggap sebagai sampah yang tidak bermanfaat. Masyarakat umumnya tidak mengetahui bahwa limbah padat tersebut masih dapat dimanfaatkan kembali. Kebiasaan yang sering dilakukan masyarakat adalah langsung membuang segala macam limbah ke dalam kantung sampah, yang kemudian berakhir pada tempat pembuangan sampah. Menurut Drs. Rasio Ridho Sani, MCOM, MpM selaku Deputi IV Bidang Pengelolahan Limbah B3 dan Sampah, hasil studi tahun 2008 yang dilakukan beberapa kota, pola pengelolaan sampah di Indonesia adalah diangkut dan ditimbun di Tempat Pembuangan Akhir (TPA) sebesar $69 \%$, dikubur sebesar $10 \%$, dikompos dan daur ulang sebesar $7 \%$, dibakar sebesar $5 \%$, dan sisanya tidak terkelola sebesar $7 \%$.
Data tersebut menunjukkan bahwa masih sangat sedikit sampah yang didaur ulang. Dalam PP RI No.81 Tahun 2012 juga disebutkan bahwa setiap orang wajib melakukan penyelenggaraan pengelolaan sampah yang meliputi pengurangan dan penanganan sampah. Pengurangan sampah meliputi pembatasan timbulan sampah, pendauran ulang sampah dan pemanfaatan kembali sampah. Informasi tentang pengelolaan sampah ini sebenarnya banyak terdapat di media massa atau internet, namun masih sedikit masyarakat yang mencari informasi tersebut. Hal ini menyebabkan kurangnya pengetahuan masyarakat tentang cara pengolahan limbah, karena itulah perlu dilakukan sosialisasi langsung kepada masyarakat. Salah satu upaya yang dapat dilakukan untuk penanganan masalah sampah tersebut adalah dengan penggunaan kantung Takakura oleh masyarakat. Masyarakat yang merupakan sasaran dari upaya ini adalah masyarakat tani di Kelurahan Kalampangan.

\section{DESKRIPSI TEORI}

\section{Sampah}

Sampah adalah bahan yang terbuang atau dibuang dari hasil aktifitas manusia maupun proses alam yang belum memiliki nilai ekonomi (E. Colink, 1996). Hadiwiyono, (1983) mengelompokkan sampah berdasarkan dua karakteristik, yaitu sebagai berikut:

(1) Kimia

a. Organik; Sampah yang mengandung senyawa organik atau sampah yang tersusun dari unsur karbon, hidrogen, oksigen, nitrogen, dan pospor. 
b. Anorganik; Sampah yang tidak dapat diuraikan oleh mikroorganisme, jika bisapun membutuhkan waktu yang sangat lama.

(2) Fisika

a. Sampah basah; tersusun dari sisa-sisa bahan-bahan organik yang mudah lapuk dan membusuk.

b. Sampah kering; digolongkan menjadi dua kelompok yaitu jenis logam seperti besi, seng, aluminium dan jenis non logam seperti kertas dan kayu.

c. Sampah lembut; berupa partikelpartikel kecil yang ringan dan mudah terbawa oleh angin.

d. Sampah besar; memiliki ukuran yang relatif lebih besar, contohnya sampah bekas mesin kendaraan.

e. Sampah berbahaya; terdiri dari sampah patogen, sampah beracun, sampah ledakan, misiu, sisa bom dan lain-lain, serta sampah radioaktif dan bahan nuklir.

\section{Komposting}

Komposting adalah adalah hasil dekomposisi sampah organik yang tidak dapat diuraikan lagi (stabil). Komposting adalah proses dimana bahan organik mengalami penguraian secara biologis, khususnya oleh mikroba-mikroba yang memanfaatkan bahan organik sebagai sumber energi. Membuat kompos adalah mengatur dan mengontrol proses alami tersebut agar kompos dapat terbentuk lebih cepat. Komposting merupakan upaya pengurangan sampah organik melalui proses atau pengolahan. Pada dasarnya semua bahan-bahan organik padat dapat dikomposkan, misalnya limbah organik rumah tangga, sampah-sampah organik pasar atau kota, kertas, kotoran/limbah peternakan, limbahlimbah pertanian, limbahlimbah agroindustri, limbah pabrik kertas, limbah pabrik gula, limbah pabrik kelapa sawit.

\section{Keranjang Takakura}

Upaya yang dapat dilakukan adalah dengan pembuatan kompos menggunakan keranjang Takakura. Keranjang Takakura merupakan alat sederhana untuk pengomposan skala rumah tangga yang ditemukan Pusdakota bersama Pemerintah Kota Surabaya, Kitakyusu International Techno-cooperative Association, dan Pemerintahan Kitakyusu Jepang pada tahun 2005. Keranjang ini dirakit dari bahan-bahan sederhana di sekitar kita yang mampu mempercepat proses pembuatan kompos. Penggunaan kantung Takakura harus dilengkapi dengan starter yang dapat diolah dengan sederhana menggunakan larutan gula, larutan garam dan nasi basi.

Keranjang Takakura atau juga dikenal sebagai Takakura Home Method (THM) Composting, adalah keranjang pembuat kompos (komposter) yang sangat ringkas dan praktis, dari bahan-bahan sederhana di sekitar kita, sehingga kita dapat membuatnya sendiri. Satu keranjang standar dengan starter berkapasitas $8 \mathrm{~kg}$, ideal dipakai oleh satu keluarga dengan jumlah total anggota keluarga sebanyak 7 orang, dimana ratarata menghasilkan sampah rumah tangga $1,5 \mathrm{~kg}$ tiap harinya. Dengan adanya kesadaran masyarakat terhadap penanganan limbah padat rumah tangga diharapkan samapah-sampah yang ada di lingkungan masyarakat dapat 
dimanfaatkan dengan sebaik-baiknya untuk pembuatan kompos.

\section{METODE}

Kegiatan ini berupa sosialisasi penggunaan kantong Takakura untuk mengurangi masalah limbah padat rumah tangga yang dilaksanakan di rumah masyarakat yang beralamat di Jalan Durian Kelurahan Kalampangan Kecamatan Sebagau Kota Palangka Raya. Jarak dari kampus ke lokasi kegiatan $\pm 10-15 \mathrm{~km}$ dan memerlukan waktu 30 menit untuk sampai di lokasi. Penyampaian materi dilakukan dengan cara ceramah dan demostrasi. Kegiatan dilaksanakan pada hari Rabu tanggal 20 Januari 2016. Waktu pelaksanaan dimulai dari pukul 13.30 sampai 17.00 WIB.

\section{PEMBAHASAN HASIL PENGABDIAN}

Hampir seluruh ibu-ibu di Kelurahan Kalampangan bekerja sebagai tani, sebagian juga PNS Guru dan lain-lain. Walaupun ibu-ibu tersebut memiliki pekerjaan sebagai tani, tetapi mereka tetap berperan sebagai ibu rumah tangga. Sebagai ibu rumah tangga, berbagai pekerjaan rumah tangga dilakukan oleh ibu-ibu di daerah ini, seperti salah satunya pekerjaan di dapur yaitu memasak. Kegiatan ibu di dapur seringkali menghasilkan limbah padat berupa limbah organik seperti limbah sayuran, nasi dan lain-lain. Limbah sayuran yang dihasilkan dari dapur rumah tangga ini biasanya dibuang begitu saja ke tempat pembuangan sampah.

Pada dasarnya, ibu-ibu tani di Daerah Kalampangan sudah pernah membuat kompos dari kotoran sapi yang ditambahkan dengan urea, namun tidak berhasil. Hal ini dikarenakan kurangnya informasi masyarakat mengenai ilmu hal-hal mendasar tentang keefektifan pembuatan kompos organik. Dengan mengetahui ilmu dan hal dasar yang disampaikan dalam sosialisasi ini, diharapkan ibu-ibu di Daerah Kalampangan dapat membuat kompos dengan teknik yang lebih baik, praktis dan efektif.

Kegiatan pengabdian masyarakat ini dilaksanakan berbarengan dengan kegiatan pengajian ibu-ibu persatuan tani Kelurahan Kalampangan. Acara dimulai dengan pembukaan oleh Ibu Sariyem dari Persatuan Tani Daerah Kalampangan Kota Palangka Raya, penyampaian materi menggunakan media leaflet dilanjutkan dengan melakukan tanya jawab dan memberikan informasi bagaimana cara proses penggunaan kantong takakura untuk mengurangi masalah limbah padat rumah tangga. Materi yang disampaikan dalam penyuluhan ini adalah membuat kompos dengan metode Takakura dan proses pembuatan starter untuk memudahkan pembusukan limbah padat rumah tangga, serta solusi penggunaan kantong takakura. Kegiatan selanjutnya adalah tanya jawab dan bagi doorprize sebagai evaluasi pemahaman peserta tentang materi yang telah disampaikan. Bagi peserta yang dapat menjawab, akan mendapat hadiah dari tim. Disediakan 20 hadiah menarik bagi 20 peserta yang dapat menjawab pertanyaan.

Kegiatan ini dapat dinyatakan berhasil karena adanya respons yang baik dan antusiasme dari ibu-ibu persatuan tani daerah Kalampangan Kota Palangka Raya selama mengikuti kegiatan dan dapat terlaksananya kegiatan sesuai dengan jadwal yang telah 
ditentukan. Kegiatan pengabdian ini diikuti oleh sekitar 50 (lima puluh) orang ibu-ibu dari persatuan tani daerah Kalampangan Kota Palangka Raya dan peserta lainnya. Kontribusi atau peran serta ibu-ibu persatuan tani daerah Kalampangan pada kegiatan ini dapat dikatakan aktif. Hal ini dapat terlihat dari perhatian, keingintahuan, serta adanya interaksi berupa tanya jawab yang dilakukan antara ibu-ibu persatuan tani daerah Kalampangan dan peserta lainnya dengan tim mengenai penggunaan kantong takakura.

\section{SIMPULAN dan SARAN}

\section{SIMPULAN}

Kegiatan Pengabdian Kepada Masyarakat mengenai "Sosialisasi Penggunaan Kantong Takakura untuk Mengurangi masalah Limbah Padat Rumah Tangga" yang dilakukan oleh Tim Dosen Program Studi Teknik Lingkungan Fakultas Teknik UM Palangkaraya ini sangat bermanfaat. Tidak hanya untuk membantu ibu-ibu untuk mempermudah membuat kompos organik, tetapi juga dapat membantu kinerja pemerintah dalam pemberian informasi mengenai pendauran ulang sampah. Kegiatan ini dapat dinyatakan berhasil karena adanya respons yang baik dan antusiasme dari ibu-ibu tani.

\section{SARAN}

Kegiatan diharapkan dapat dilaksanakan secara berkelanjutan ke organisasi atau perkumpulan wanita lain, tidak hanya di organisasi atau perkumpulan wanita saja tetapi dapat dilaksanakan di Tempat Pembuangan Akhir Sampah. Diharapkan LP2M UM Palangkaraya dapat terus mendukung kegiatan pengabdian masyarakat ini, misalnya dengan melaksanakan program pengabdian minimal dua kali dalam setahun dalam berbagai bidang ilmu pengetahuan. Semakin sering diadakan Kegiatan Pengabdian Kepada Masyarakat ini maka jumlah peserta lebih banyak serta bervariasi. Dengan intensitas pengabdian yang lebih sering, dapat lebih banyak melibatkan mahasiswa sebagai sarana mahasiswa belajar mengaplikasikan ilmunya kepada masyarakat dan semakin meningkatkan pengetahuan serta kesadaran masyarakat tentang pembuatan kompos dengan menggunakan kantong takakura.

\section{DAFTAR PUSTAKA}

Peraturan Pemerintah Republik Indonesia Nomor 81 Tahun 2012 tentang Pengelolaan Sampah Rumah Tangga dan Sampah Sejenis Sampah Rumah Tangga.

E. Coling, 1986, Istilah Lingkungan Untuk Manajemen.

Hadiwiyono, 1983, Penerangan dan Pemanfaatan Sampah. Idayu, Jakarta. 